\title{
Het beeld van Midden- en Oost-Europa in Nederlandse literaire non-fictie
}

\author{
JO STERCKX \\ Adam Mickiewicz University \\ Wydział Anglistyki \\ Uniwersytet im. Adama Mickiewicza \\ al. Niepodległości 4 \\ 61-874 Poznań, Poland \\ jsterckx@wa.amu.edu.pl
}

\section{The image of Central and Eastern Europe in Dutch literary nonfiction}

\begin{abstract}
Over the last 20 years, literary nonfiction has become increasingly popular among the Dutch reading public. Thanks to increasing sales, translations and literary awards the genre achieved a strong position in Dutch literature. This article analyzes the image of Central and Eastern European countries in Dutch literary nonfiction of the last ten years (2004-14). It searches for characteristics of an orientalist and balkanist discourse and the presence of the imagological centre-periphery model in the works of Geert Mak, Jelle Brandt Corstius, Olaf Koens, Joop Verstraten and Jan Brokken. Contemporary Dutch literary nonfiction contains a euro-orientalist discourse. Characteristics such as underdevelopment, hedonism, obscurity and authenticity are projected on Central and Eastern Europe, which is put in the periphery of Western Europe.
\end{abstract}

Keywords: literary nonfiction; Dutch literature; euro-orientalism; balkanism; imagology; centre-periphery model; Central and Eastern Europe

\section{Nederlandse literaire non-fictie}

Geert Maks Hoe God verdween uit Jorwerd (1996) wordt beschouwd als de Nederlandse doorbraak van literaire non-fictie waarvan in feite sporen uit de negentiende eeuw te vinden zijn. In 1899 beschreef De Telegraaf-journalist Bernard Canter, die beïnvloed was door het realisme en naturalisme, zijn ervaringen 
als bedelaar in Twee weken bedelaar. In de $20^{\text {ste }}$ eeuw was de sterke persoonlijke aanwezigheid van de journalist zichtbaar in het opinieweekblad de Haagse Post (ter ziele gegaan in 1990), het modetijdschrift Avenue en De zaak 40/61 (1961) van Harry Mulisch (Mourits 2008: 14-16). Literaire non-fictie wordt gekenmerkt door zowel literaire technieken (personages, scènes) als journalistieke feitelijkheid. Haar succes bij het Nederlandse lezerspubliek is grotendeels te verklaren door een verlangen naar herkenning en canonisatie van het eigen verleden. Ook de celebritycultuur rond schrijvers en journalisten en het verlangen naar waargebeurde verhalen spelen op dit vlak een belangrijke rol (Ceelen en Bergeijk 2007: 7-15). Literaire nonfictie is reeds op verschillende wijzen gedefinieerd. Fortuin (2008: 59-60) stelt dat literaire non-fictieschrijvers, meestal journalisten, op de voorgrond willen treden als meeslepende vertellers en zich willen onderscheiden van "gewone" non-fictie, die steunt op de overdracht van kennis, de kwaliteit van het onderzoek en de kracht van de analyse. Voor Lievers (2008: 102) zijn de reisverhalen van Cees Nooteboom het schoolvoorbeeld: enerzijds moeten de neergeschreven feiten correct zijn, anderzijds moeten de feiten zo worden weergegeven dat de stem van de auteur continu aanwezig is en een toegevoegde waarde vormt bij het feitenmateriaal. Mourits (2012: 28) stelt dat de term "literair" niet gehanteerd wordt om een indicatie te geven van de kwaliteit van een tekst, maar gebruikt wordt voor marketingdoeleinden.

Dat literaire non-fictie een sterke positie heeft verworven in de Nederlandstalige literatuur is een vaststaand feit, wat niet alleen uit de hoge verkoopcijfers, maar ook uit grote aantal vertalingen blijkt. In 2010 stipuleerde het beleid van het Nederlands Letterenfonds dat literaire non-fictie een belangrijk onderdeel vormt van de internationale promotie van de Nederlandstalige literatuur (Valken 2012). ${ }^{1}$ In 2013 verschenen in totaal 392 vertalingen van Nederlandstalige literatuur uit Nederland en Vlaanderen, verdeeld over fictie (136), non-fictie (76) en reisliteratuur (10) (Nederlands Letterenfonds 2013). Sinds 1998 organiseert het Nederlands Letterenfonds een tweejaarlijkse conferentie voor schrijvers, vertalers en uitgevers van non-fictie waarop de ontwikkelingen in het genre worden besproken. Bovendien kan het genre rekenen op verschillende nominaties voor Nederlandse, Vlaamse en internationale literaire prijzen. ${ }^{2}$ Nadat de

\footnotetext{
${ }^{1}$ Samen met Nederland zal Vlaanderen in 2016 het gastland zijn tijdens de Boekenbeurs van Frankfurt en zal volgens de Vlaams Minister van Cultuur Joke Schauvliege "het groot potentieel aan Vlaamse literaire non-fictie ruim aan bod komen" (Schauvliege 2014).

${ }^{2}$ Zo ontving Geert Mak voor In Europa de NS Publieksprijs voor het Nederlandse Boek (2004) en de Leipziger Buchpreis zur Europäischer Verständigung (2008). Joris Luyendijk won met Het zijn net mensen (2006) de Dick Scherpenzeelprijs en de NS Publieksprijs en als allereerste niet-Fransman de Prix des Assises du journalisme. Voor El Negro en ik (2004) ontving Frank Westerman in 2005 de Gouden Uil Literatuurprijs en in 2002 won Judith Koelemeijer de Publieksprijs voor het Nederlandse boek voor Het Zwijgen van Maria Zachea (2001). De Vlaamse Lieve Joris werd bekroond met verschillende onderscheidingen, onder andere de Cultuurprijs van de Vlaamse Gemeenschap in 1999 voor Mali Blues (1996).
} 
categorie non-fictie in de Gouden Uil Literatuurprijs na 1999 was vervangen door de Prijs van de Lezer, werd literaire non-fictie ondergebracht bij de Literatuurprijs, hetgeen een indicatie was voor het steeds dichter naar elkaar toegroeien van literaire fictie en non-fictie. De toekenning van de Libris Literatuurprijs, de AKO Literatuurprijs en de Jan Greshoffprijs aan Congo: Een Geschiedenis van de Vlaming David Van Reybrouck vormde in 2010 een hoogtepunt.

Internationaal onderzoek naar de hedendaagse West-Europese beeldvorming van Midden- en Oost-Europa (de MOE-landen) heeft zich voornamelijk toegespitst op de Britse en Duitse pers. ${ }^{3}$ Dit artikel probeert te achterhalen welk beeld er van de MOE-landen wordt getoond in het werk van literaire non-fictieauteurs zoals Geert Mak, Jelle Brandt Corstius, Olaf Koens, Joop Verstraten en Jan Brokken. ${ }^{4}$ Ten eerste werd er gezocht naar karakteriële toekenningen die een indicatie kunnen zijn van een oriëntalistisch en een balkanistisch discours. Volgens Edward Said (Orientalism, 1978) worden in een oriëntalistisch discours aan het MiddenOosten en Verre Oosten (voornamelijk de Arabische en islamitische wereld) kenmerken toegekend zoals onderontwikkeling, wreedheid, genotzucht, irrationaliteit, lusteloosheid, exotiek en mysterie (Baldwin 2000: 169-171). Maria Todorova stelt in Imagining the Balkans (1997) dat de Balkan, in tegenstelling tot de ondefinieerbare Oriënt, een historische en geografische duidelijkheid kent. De Oriënt diende als een escapistisch droomoord en als exotisch rijk (Utopia), groeide uit tot een metafoor voor het verbodene met een expliciete relatie tussen het Oosten, het vrouwelijke en de lust. Zuidoost-Europa, i.e. de Balkan, bracht eerder een negatieve, onverbloemde en ongenuanceerde attitude teweeg, zonder het mysterieuze, exotische en seksuele, maar met een mannelijke aantrekkingskracht. Eigenschappen die aan de Balkan worden toegekend zijn o.a. geweld, wreedheid, etnische complexiteit en gedrag gebaseerd op culturele tradities (Todorova 1997: 11, 13-14, 118).

Ten tweede werd in dit onderzoek het imagologische centrum-periferiemodel gehanteerd. De relatie tussen centrum en periferie is niet van ruimtelijke aard maar is gebaseerd op macht en prestige. Het centrum wordt beschouwd als dynamisch, progressief, verfijnd en modern, terwijl de periferie waargenomen

\footnotetext{
${ }^{3}$ Hudabiunigg, Ingrid. 2004. "The otherness of Eastern Europe," Journal of Multilingual and Multicultural Development 25: 369-388. Alpion, Gëzim. 2005. Western Media and the European "Other": Images of Albania in the British Press in the New Millennium. Albanian Journal of Politics. I (1): 4-25. Fleming, Michael. 2005. "The use of stereotypes in the British media during the period of European Union expansion in 2004: The representation of post-communist states," Sprawy Narodowościowe 26: 19-27. Mockutè, Miglè. 2008. "The images of the Baltic States in the international media upon accession to NATO and the EU," Lithuanian Foreign Policy Review 21: 10-37.

${ }^{4}$ Het artikel maakt deel uit van een onderzoek naar de evolutie van het beeld van Midden- en OostEuropa in Nederlandse culturele teksten zoals nieuwsmedia, televisieprogramma's en literatuur (1980-2010).
} 
wordt als statisch, traditionalistisch, onderontwikkeld en ouderwets. Zo kan een urbaan gebied (bv. de hoofdstad) het centrum vormen van perifere rurale gebieden (bv. de provincies). Hele continenten zoals Europa (eurocentrisme) en Noord-Amerika kunnen in het centrum geplaatst worden, tegenover perifere werelddelen zoals Afrika en Azië. De periferie kan ook refereren naar delen van de samenleving die niet betrokken zijn in macht- en cultuurnetwerken zoals achterbuurten van metropolen (Chew III 2006: 184-185, Leerssen en Beller 2007: 278-280).

\section{Geert Mak: In Europa (2004)}

Voor het lezerspubliek representeert Geert Mak de verhoopte geschiedenisleraar van wie de boeken een houvast bieden in een snel veranderende en identiteitszoekende samenleving. Mak verbindt persoonlijke verhalen met algemene geschiedenis en wordt bekritiseerd vanwege feitelijke onvolledigheden, zijn belerende toon en zijn neiging tot nostalgie, waardoor er een zoektocht ontstaat naar een verloren, harmonieuze en gelijkmoedige gemeenschap (Broer 2004, Ceelen en Bergeijk 2007: 105-108). In Europa heeft intussen vijftien drukken, veertien vertalingen (waaronder het Engels en het Pools), een verkochte oplage van ca. 450.000 exemplaren en een 35-delige verfilming (VPRO, 2007). In twaalf hoofdstukken keert Mak terug naar sleutelgebeurtenissen in de $20^{\text {ste }}$-eeuwse geschiedenis en wisselt geschiedkundige passages met individuele getuigenissen af met zijn eigen indrukken van de hedendaagse gesteldheid van de bezochte landen en steden. In deze persoonlijke sfeer- en natuurbeschrijvingen, die typisch zijn voor literaire non-fictie, toont Mak een beeld van de MOE-landen dat gekenmerkt is door achtergesteldheid (onderontwikkeling), wreedheid, genotzucht en authenticiteit.

Een indicatie van de aanwezigheid van het IJzeren Gordijn in het boek is de vrijwel volledige negatieve portrettering van de voormalige Oostbloklanden naast het geheel positieve beeld van Istanboel dat exotisch, levendig en gastvrij is. Mak looft het multiculturele karakter, de keuken, de ouderwetse grandeur en de geseculariseerde staat. Ondanks de oostelijke geografische positie worden er aan Turkije, dat tot het einde van de Koude Oorlog tot het Westblok behoorde, geen negatieve karakteristieken toegekend (Mak 2004: 657).

Van vrijwel elk MOE-land beschrijft Mak de aftandse transportmiddelen en zijn armoedige en alcoholdrinkende travelees, terwijl deze thema's tijdens zijn omzwervingen in West-Europa nauwelijks aan bod komen. Tijdens een treinreis van Berlijn naar Wenen beschrijft hij in Tsjechië de duistere omgeving, de ouderwetse restauratiewagen, het zwaarmoedige personeel 
en het sneeuwachtige landschap vol roestige industriële overblijfselen. Van Finland naar Sint-Petersburg neemt de leegheid en doodsheid van de omgeving toe naarmate de Fins-Russische grens nadert. Eenmaal de grens overgestoken passeert hij een "grijze" stad en ziet hij vissers op een bevroren rivier en oude vrouwen die augurken en wodka verkopen. De grens is nu "echt" overgestoken. De Russen zijn het slachtoffer van een machteloze overheid en van een wurgende onderwereld. Bovendien is de Russische samenleving gespleten en onegalitair als gevolg van "kapitalistische enclaves." In Volgograd, "waar ze van gsm nog nooit gehoord hebben," beschrijft Mak de grimmigheid en loomheid, reizend langs de "eindeloze" Wolga en "eenzame" telefoonpalen. Zijn vooropgezet denkbeeld van Oost-Europese vrouwen botst met de "verrassende" elegantie en kledij ("kortrokkig," "wijde open blouse"). In een nachtclub suggereert Mak dat zijn opdienster een prostituee is vanwege haar kleding en erotiseert dusdoende de Russische vrouw. De positieve toekenningen aan Rusland zijn de professionele ambitie en het authentieke oosters-orthodoxe geloof (Mak 2004: 201, 208-210, 579-580, 590-591, 627-628, 632).

Oekraïne wordt voorgesteld als corrupt en extreem verdeeld tussen enerzijds de rijken en Westerse toeristen en anderzijds de arme zwoegers. Mak neemt een standpunt in tegen culturele globalisering en westerse, kapitalistische invloed. In de havenstad Odessa aan de Zwarte Zee is het authentieke geluid van de zee vervangen door terrasjes die geteisterd worden door frisdrankreclames en oorverdovende muziek. Mak is teleurgesteld vanwege de veranderingen die hebben plaatsgevonden in Rome waar hij aan het begin van de jaren 1980 verbleef. Zo zijn veel kruidenierszaken, het drogende wasgoed in de smalle straatjes en de rode pannendaken verdwenen. In zijn ogen authentieke en volkse fenomenen hebben plaatsgemaakt voor onechte en kosmopolitische kenmerken (Mak 2004: 643-644, 650, 654-656, 688).

Tijdens een treinreis in Litouwen, "in de eindeloze sneeuw," drinkt Mak wodka met zijn travelee die uitvoerig praat over "Litouwse treinhoeren." In Vilnius, waar "de Westerse trutterigheid met volle kracht heeft toegeslagen," toont de auteur zijn lichte afkeer van het Westen, alsof de in zijn ogen authentieke Litouwse cultuur wordt beschadigd door westerse invloeden. Zijn beschrijving van armoedige woningen, sombere overheidsgebouwen, alomtegenwoordige kraaien en het hoge nationale zelfmoordpercentage leidt tot een beeld van obscuriteit. Mak toont twee positieve beelden van de Baltische staten. Estland heeft na 1989 een goede internationale reputatie opgebouwd en de aangename Letse hoofdstad Riga heeft "iets intiems, Deens en sfeervols, met een schijn van Deventer." Litouwen wordt in de periferie en Estland en Letland worden in het centrum geplaatst (Mak 2004: 236, 242-243). 
Het imagologische centrum-periferiemodel is eveneens zichtbaar in het beeld van Tsjechië, Hongarije en Dresden, de hoofdstad van de Duitse deelstaat Saksen. In Dresden, het centrum, bewondert Mak de prachtige architectuur en aan de Elbe, in de richting van de Tsjechische grens, prijst hij de natuurlijke en menselijke taferelen. Eenmaal in Tsjechië, het begin van de periferie, wordt het beeld plotseling gedomineerd door straathandel, industriële monumenten, milieuvervuiling, prostitutie, ouderwetsheid en het doodgereden wild op straat. Ten zuiden van de "wilde" Hongaarse hoofdstad Boedapest, reizend langs een "eindeloze" vlakte, straatprostituees en paardenkarren, registreert Mak de melancholische getuigenissen over het harde leven onder het kapitalisme (Mak 2004: 764-765, 788-789, 824).

In de beschrijving van Zuidoost-Europa zijn verschillende balkanistische toekenningen terug te vinden. Op weg naar de Roemeense hoofdstad reist Mak langs dorpen "die nauwelijks veranderd zijn sinds 1880." De Roemeense samenleving wordt als zonderling voorgesteld: religie en kapitalisme leven in een vreemde symbiose en de twee miljoen inwoners van Boekarest leven tussen 200.000 straathonden. Mak portretteert de Roemenen als unaniem nostalgisch naar de communistische tijd. Positieve gevolgen van de democratisering komen niet ter sprake. In Servië staat de enige positieve eigenschap, gastvrijheid, eenzaam tegenover armoede en geweld. Communistische vredelievendheid wordt gecontrasteerd met nationalistische vernietigingskracht. De beschrijving van Bosnië en Herzegovina is stereotypisch. In Sarajevo beschrijft hij een "pittoresk" oud vrouwtje, nationalistische vetes, armoede en doodse stilheid en in Srebrenica interviewt hij alleen plaatselijke dronkaards (Mak 2004: 1031, 1033, 1038-1041, 1081, 1084).

In het hoofdstuk over de havenstad Gdańsk worden aan Polen genotzucht (alcoholmisbruik) en onderontwikkeling toegekend. Tijdens een avondmis aanschouwt Mak met verbazing "jongens met opgeschoren koppen die de kalk van het plafond bidden, dames in bontjassen, mannen in gewatteerde jacks en huismoeders met bolle alpinomutsen." Een Poolse jongeman is volgens de auteur ofwel een dichter ofwel een hooligan, maar altijd romantisch-nationalistisch, verliefd en depressief. Tijdens een ontmoeting met een Poolse historicus benadrukt hij de hoge alcoholconsumptie van zijn gesprekspartner en diens vriendin met wie hij "in een aangename somberheid" vervalt. In de Warschau-Moskou-expres wordt "vastberaden" gedronken en van alle mogelijke treinreizigers vermeldt hij uitsluitend een halfnaakte man en een vrouw in een roze beha. Aan de WitRussische grens verkopen vrouwen "zichzelf" en in de restauratiewagon zit een vrouw "met vette haarslierten" die hem het hof maakt, en een dansende en wodkadrinkende vrouw. Aan de Pool wordt passiviteit toegekend aangezien 
"werken nog altijd een vervelende, noodzakelijke activiteit is die je zoveel mogelijk ontloopt en waaruit je alles probeert te halen voor je privébestaan." Een typisch Pools gehucht bestaat uit "kippen, ganzen, een kettinghond, drie oude vrouwen en een boer op een kar" (Mak 2004: 535, 991-993, 999-1004).

\section{Correspondenten: Jelle Brandt Corstius en Olaf Koens}

Rusland voor gevorderden (2008) is een bundel van Trouw-artikels gepubliceerd tussen april 2005 en mei 2007 van de voormalige Moskou-correspondent Jelle Brandt Corstius. ${ }^{5}$ Zijn oeuvre maakt geenszins toeristische reclame voor Rusland, tenzij de lezer houdt van alcoholisme, irrationeel gedrag, corruptie en desorganisatie. Dat de auteur Rusland "overleefd heeft" en personen met een voorliefde voor Rusland "een steekje los hebben," duidt op zijn problematisering van het land. Op de achterflap wordt zelfs achterhaalde koudeoorlogsretoriek gebruikt (de "sovjetflat" van de auteur en "het Oostblok"). In de negen hoofdstukken, over reizen naar Altaj, Kazachstan, Moskou, de Nenetsen, Armenië, Moermansk en de Kaukasus, worden mysterie, achtergesteldheid, absurditeit en genotzucht toegekend (Brandt Corstius 2008: 122-123).

Brandt Corstius' bezoek aan de Russische deelrepubliek Altaj staat in het teken van het onverklaarbare waarbij hij op zoek gaat naar een "mysterieuze" godsdienst (het Boerchanisme), passerend langs "mysterieuze" dorpen en vrouwen. Absurde taferelen tijdens douanecontroles vormen de kernonderwerpen. Zijn Nederlandse identiteit staat in een culinaire clash met de Russische identiteit: zijn travelees verkiezen hompen en blikken "goor" vlees boven zijn gezonde pasta met tonijn en hun overmatige alcohol- en voedselconsumptie staat in schril contrast met zijn matiging. De voortdurende beschrijving van het uiterlijk van de bevolking en de doorreisplekken zorgt voor een beeld van achtergesteldheid. Zo ontmoet hij "een man met drie tanden," "een jongen op blote voeten," "een zuster met een paar tanden" en "een lokale maffioso met een dikke pens." Onderweg bezoekt hij "een primitief hotel," "een ongure stad," "een buitenaards dorp" en "een shitdorp" (Brandt Corstius 2008: 10, 11, 16, 20, 22, 24).

In plaats van een hedendaags Kazachs restaurant te tonen, wordt de lezer meegenomen naar een "rare" stolovaja, een soort bedrijfskantine die stamt uit de Sovjetperiode. In Kazachstan trotseert hij "treurnis en kou," "obscure" en "smoezelige" mannen en "marteldouches" in de hotelkamers, maar

\footnotetext{
${ }^{5}$ In 2014 schreef Brandt Corstius het Boekenweekessay, Arctisch dagboek, in navolging van andere non-fictieschrijver zoals Lieve Joris (1991), Geert Mak (1998) en Adriaan van Dis (2004). Literaire nonfictie heeft zich dus ook geprofileerd in de Boekenweek, een jaarlijks terugkerende periode in maart ter promotie van het Nederlandstalige boek.
} 
vermeldt hij geen positieve aspecten van de economische vooruitgang zoals de nieuwbouwprojecten in de hoofdstad Astana. Integendeel, de stad wordt beschreven als een desolate en bombastische stad waarvan de hoofdarchitect "een soort Kazachse Albert Speer" is, met bijzonder duistere associaties tot gevolg (Brandt Corstius 2008: 29, 33, 35, 43).

In het grotendeels negatieve beeld van Moskou ligt de nadruk op vreemde absurditeiten, "mysterieuze" beroepen zoals de "roltrapdienster" in de "stinkende" metro vol gewiekste handelaars en waar luidsprekers de reizigers "bombarderen" met westers geïnspireerde reclame. In een conversatie met zijn huisbaas, waaruit moet blijken dat een huurder geen rechten heeft, wordt het beeld van onbetrouwbaarheid gevormd. In Rusland is de relatiehiërarchie van belang en is te laat komen voor een afspraak de gewoonte. De Russische vrouw wordt veralgemenend als zwak voorgesteld ("het is een compliment als je haar een 'weak lady' noemt"), en een typische Kaukasische vrouw heeft zwart haar en een snor. "Extreme" gastvrijheid wordt toegekend aan de Kaukasus. Het laatste van de negen hoofdstukken ("Alcohol") is volledig gewijd aan drankuitspattingen en bezoeken aan datsja's. De auteur stelt onomwonden dat het stereotype van de dronken Rus op waarheid berust en weigert bijna nooit een aangeboden glas wodka. In de als onbeschaafd voorgestelde havenstad Kem koopt hij een kaartje "voor de eerste trein naar de beschaving" richting Finland (Brandt Corstius 2008: 49-53, 57, 66-74, 133, 149-150, 163, 174).

Kleine landjes. Berichten uit de Kaukasus (2009) is gebaseerd op reportages voor het dagblad Trouw gepubliceerd tussen april en oktober 2008 en toont een beeld van onderontwikkeling en gastvrijheid. Het boek neemt de lezer mee naar Tsjetsjenië, Abchazië, Kalmukkië, Karatsjaj-Tsjerkessië en Ossetië en is gekenmerkt door dramatiserend, soms ridiculiserend taalgebruik. Brandt Corstius zoekt het obscure en het vreemde dat hij meent te vinden "in het rariteitenkabinet" van de Kaukasus "waar de tijd ergens in de Middeleeuwen stil is blijven staan." In Tsjetsjenië focust hij op armoede, geweld, verticale machtsverhoudingen en het gebrek aan persvrijheid. Zijn egalitaire denkwijze is zichtbaar wanneer hij een luxueus restaurant als "afschuwelijk elitair" bestempelt. Ook vrouwenroven komen aan bod: "Misschien lag er een noodzakelijk verband tussen het drinken van rauwe knoflook en het stelen van vrouwen," is één van de dooddoeners. Typisch voor literaire non-fictie zijn de abrupte anekdotes uit zijn persoonlijke verleden. Zo verwijst hij naar een ex-vriendin die hij verliet wegens "haar algemene vragen en opmerkingen." In Kalmukkië blikt hij terug op een reis naar Bangkok en klagend over de Georgische bureaucratie vermeldt hij de inefficiëntie van het hoofdkantoor van Artsen zonder Grenzen in Parijs (Brandt Corstius 2009: 9-10, 14-20, 24, 38, 54, 61, 92, 98, 115). 
Het als chaotisch voorgestelde Abchazië wordt identiek bevonden aan "het lelijke roversnest" Kosovo, aan de hand van de aanwezige VN-macht, de drang naar onafhankelijkheid en "shady" figuren. De lokale journalist Zjenja wordt omschreven als een elegante, Engelsprekende contactpersoon die echter op Borat lijkt. ${ }^{6}$ Brandt Corstius ridiculiseert verder de prostitutie in de Russische badplaats Sotsji: "Ik was al bang om de garderobekast te openen, omdat er wel eens een meisje uit zou kunnen donderen." Zijn beeld van Ossetië is gekenmerkt door gastvrijheid en hij focust op de persoonlijke verhalen tijdens het gewapende conflict in Zuid-Ossetië tussen Georgische en Russische troepen dat officieel duurde van 7 tot 16 augustus 2008. Toch geeft hij ook kritiek op het vervormde westerse mediabeeld over het conflict (Brandt Corstius 2009: 80-82, 98, 102-103, 109, 139-140).

In tegenstelling tot Brandt Corstius voorziet de huidige Rusland-correspondent Olaf Koens een bibliografie en registerlijst in Koorddansen in de Kaukasus (2012), een bundel reportages uit o.a. Georgië, Armenië, Azerbeidzjan, Dagestan, Ingoesjetië en Tsjerkessië. De vergelijking tussen beide correspondenten kan gemaakt worden omdat voor een groot deel dezelfde plaatsen en onderwerpen aan bod komen. ${ }^{7}$ Koens alinea's zijn beduidend langer, de interviews zijn volledig uitgeschreven, waardoor de registratie van de gebeurtenissen zuiverder is, en het boek bevat meer politieke en economische achtergrondinformatie. Hij toont een positiever en evenwichtiger beeld dan Brandt Corstius, maar plaatst de Kaukasus in de periferie ("Ruslands onbeheersbare achtertuin") van het centrale Moskou. Zijsprongen naar zijn persoonlijke leven en het beeld van de drinkende Rus zijn nauwelijks aanwezig (Koens 2012: 38, 41).

Toch zijn er een aantal stereotypische toekenningen. De correspondent beklemtoont regelmatig de sensualiteit van zijn vrouwelijke travelees waardoor er een exotisch vrouwenbeeld ontstaat: "een blonde vrouw op hoge hakken," "een hoogblonde assistente," "serveersters die wulps om de mannen heen draaien," "speelse ogen" en "Armeense vrouwen die iets bijzonders hebben." Ook achtergesteldheid en onbetrouwbaarheid zijn toegekende eigenschappen. In het Abchazische dorp Adzjoebzja "lijkt het alsof de tijd wel vijftig jaar heeft stilgestaan." In de "cynische en megalomane" Tsjetsjeense hoofdstad Grozny is corruptie normaal en vormen interpersoonlijke relaties het uitgangspunt

\footnotetext{
${ }^{6}$ Borat Sagdiyev is een fictieve Kazachse journalist, die wordt gespeeld door de Britse komiek Sacha Baron Cohen. De polygame en antisemitische Borat heeft een slechte relatie met zijn moeder, seksuele betrekkingen met zijn zussen en een grote bewondering voor dictators zoals Stalin. Het personage speelde de hoofdrol in de mockumentary Borat: Cultural Learnings of America for Make Benefit Glorious Nation of Kazakhstan (2006).

${ }^{7}$ Zo behandelen beide auteurs de Moskouse datsja van voormalig Sovjetdictator Stalin, de oorlog in Zuid-Ossetië in 2008, het voormalige apenkweekstation in het Abchazische Soechoemi en de Olympische Winterspelen in het Russische Sotsji in februari 2014.
} 
voor zaken. Het boek bevat ook een reportage over het trainerschap in 2011 aan de voetbalploeg Terek Grozny van de Nederlander Ruud Gullit, die zich moeilijk kan aanpassen aan het land. In dit deel wordt Tsjetsjenië, gekenmerkt door verticale hiërarchie, corruptie en absolute macht, scherp gecontrasteerd met Nederland. Koens probeert echter ook de normaliteit te tonen door de vermelding van de toekomstverwachtingen van enkele plaatselijke jongeren. Een ander normaliserend thema is populaire cultuur: zo interviewt hij de leden van de rockband G-Town (Koens 2012: 28, 31-32, 36-38, 46, 49, 53-55, 70, 124, 194).

Dagestan, een autonome republiek van de Russische Federatie, wordt als wild voorgesteld in de passage over een taxichauffeur die met een kapmes naar omstanders zwaait. Georgische kenmerken zijn wildheid, chaos, patriarchale gewoontes en een paradoxaal uiterlijk. Het Georgische beeld bevat ook een positief element vanwege de beschrijving van een feestje dat ook in een hippe West-Europese stad had kunnen plaatsvinden. Ook in deze passage toont Koens een evenwichtig beeld van de Kaukasus. Aan het einde komt zowel een romantisch beeld als een beeld van wildheid naar voren. Dankzij het rijden op "een vuurpaard met een eigen karakter" voelt hij de vrijheid van de wilde, patriarchale en wrede Kaukasus waar volgens hem eerlijke en eenvoudige regels heersen en heb je weinig nodig, behalve een paard en een dolk (Koens 2012: 118121, 134, 195, 205-206, 208-210, 240).

\section{Reisverhalen: Joop Verstraten en Jan Brokken}

In Verhalen van de jongste tijd. Reizen langs de rafelranden van het Sovjetblok (2008) baseert reisauteur Joop Verstraten zich op zijn doorreizen door Middenen Oost-Europa. Geschiedkundige passages over onder andere de Tweede Wereldoorlog en de revoluties in 1989 staan naast zijn persoonlijke indrukken van de hedendaagse gesteldheid van o.a. Oekraïne, Polen, de oblast Kaliningrad, Roemenië en Moldavië. Het boek bevat geen datums waardoor de lezer uit de tekst moet afleiden wanneer de reportages werden geschreven. Kenmerkend is het beeld van duisternis en onderontwikkeling. Het beeld van Tsjechië bestaat uit onderontwikkeling: "een grauwe beklemming over sommige volwassenen," "een scharminkelig paard," "troosteloze flatgebouwen" en "kitscherige aankleding" in hotels. Helemaal negatief is het beeld van het duistere en onderontwikkelde Roemenië. Zo beschrijft hij een vrouw als "een grijze schim," het land als "de Derde Wereld in het hartje van Europa," "vale, grauwe, miserabele mensen" en "door inteelt opgekrikte dommigheid die van de gezichten afspat." Het beeld van Boekarest wordt gevormd door "grauwe flats" en "een ritselaar en sjoemelaar" 
die als gids werkt. Verder maakt de auteur gewag van "typische Oostblok extraatjes zoals nachtelijke telefoontjes op je hotelkamer met aanbiedingen voor een massage of erger" en betitelt hij jonge mannen in leren jasjes gratuit als "gangsters in spe" (Verstraten 2008: 17, 21, 26, 28-31, 36-37, 39-44, 59-64).

Verstraten gebruikt een balkanistisch discours in de beschrijving van Zuidoost-Europa, dat wordt omschreven als "een etnische soep." Het beeld van Macedonië bevat positieve elementen zoals gezelligheid, optimisme, ondernemerschap, een relaxte sfeer en "de plezierige zelfverzekerdheid" van vrouwen. Verstraten beklemtoont echter ook de blik naar het verleden, ziet "vale mensen in het grauwe Debar" en omschrijft de oorlogen in Ex-Joegoslavië in de jaren 1990 als "de Joegoslavische Pest." Een plaatselijke vrouw is "zoals het hoort in het zwart gekleed," de Balkan heeft "een gewelddadige reputatie" en "een religieuze inborst" en de inwoners "maken ruzie over alles wat met etniciteit te maken heeft." Zijn negatieve beeld van Albanië is volledig gekenmerkt door achtergesteldheid: het land is geëvolueerd van "Europees Noord-Korea" naar “Europees Somalië" (Verstraten 2008: 71-75, 79, 84-86, 92, 95).

In het als onderontwikkeld voorgestelde Moldavië verblijft Verstraten in een hotel "in Sovjetsnit - beton, lomp en vierkant." Een bezochte nachtclub heeft "een onbeschrijflijke troosteloosheid: leeg, donker, verkeerde muziek en suïcidaal ogende barkeeper." De auteur noemt het land regelrecht "een bananenrepubliek" waar mensen "grauwe, gegroefde hoofden" hebben. In de hoofdstukken over Zuidoost-Europa en de Baltische staten is de tegenstelling centrum versus periferie aanwezig. Verstraten plaatst "schobbejak" Servië in de periferie van "het volwaardige EU-lid Slovenië." Van de Baltische staten, het centrum, is er een positief beeld. De Litouwse hoofdstad Vilnius is "mooi op een nostalgische, romantische manier" met "rustige, zelfverzekerde mensen." In Estland krijgt hij "het gevoel dat het Scandinavië is. Esten zijn Europeanen geworden." Paradoxaal is de omringing van oude "typisch Midden-Europese" mooie binnensteden "door onleefbare betonwoestijnen" uit de Sovjetperiode. In het "troosteloze" Kaliningrad, de periferie, contrasteert hij het lelijke Huis der Sovjets met mooie Duitse villawijken en beklemtoont hij de armoede, prostitutie en corruptie (Verstraten 2008: 101-102, 108-110, 120-121, 128, 131-133, 217-218, 221, 226).

Oekraïense vrouwen worden als exotisch voorgesteld. In Jalta aanschouwt de auteur "elegante en verzorgde vrouwen" die een zelfbewuste en feestelijke indruk maken. Oekraïense mannen zijn daarentegen onelegant en hebben "foute kapsels en kledij." De auteur gebruikt koudeoorlogsretoriek ("Oostblokhotels") en veroordeelt de kloof tussen arm en rijk en het tonen van rijkdom via bv. geblindeerde auto's met privéchauffeurs ("een exhibitionistische vulgariteit"). 
Verstraten vertoont ook een paternalistische houding: "Lviv zou er goed aan doen een van haar voormalige joodse burgers wat meer te koesteren." Enerzijds beschouwt hij alle restanten uit de Sovjettijd als minderwaardig, anderzijds bekritiseert hij westerse invloeden zoals "wansmakelijke" Amerikaanse muziekvideoclips. De muziekzender MTV, de fastfoodketen McDonalds en de filmindustrie in Hollywood zijn volgens hem "illusies." De financiële aantrekkingskracht van westerse landen is "de voze schijn van vleespotten" en hij veronderstelt dat oosterse migranten in het westen vanzelfsprekend gediscrimineerd zullen worden (Verstraten 2008: 135, 237, 242-243, 254, 264, 268, 297-298).

Zowel in de Nederlandse als Vlaamse pers werd Baltische Zielen (2010) van de voormalige Haagse Post- en Trouw-journalist Jan Brokken positief beoordeeld. ${ }^{8}$ Brokken portretteert vijftien Baltische kunstenaars en intellectuelen die in hun succesvolle carrière de landsgrenzen konden doorbreken, zoals de schilder Mark Rothko en de filosofe Hannah Arendt. In het boek worden levensverhalen afgewisseld met persoonlijke impressies van Brokken die tussen 1999 en 2010 zes keer naar Estland, Letland, Litouwen en Kaliningrad reisde. Brokken beschouwt de regio als puur en authentiek. In Estland reist hij langs "uitgestrekte bossen, waar nergens dorpen of bebouwing is." De charme van de vooroorlogse houten huizen in het Oost-Litouwse dorpje Švenčionys staat in schril contrast met de hoge flats "die de Sovjets tussen de oorspronkelijke woningen hebben neergekwakt." Tijdens een busreis naar de Estse hoofdstad Talinn mijmert Brokken dat "sneeuw alles stil maakt. Alle passagiers zitten naar buiten te staren. Geen gepraat, geen getelefoneer; dit landschap dwingt tot mijmeren." In de Alexander Nevskikathedraal in Talinn hoort hij "gezang zo zuiver en toonvast dat ik vermoed dat het uit een luidspreker komt" (Brokken 2010: 14, 126, 309, 319, 334).

Baltische zielen toont ook een beeld van onderontwikkeling. Vlak voor de aanvang van een concert van het Lets Nationaal Symfonie Orkest registreert Brokken:

Ik merk weinig van die lange, rijke voorgeschiedenis van het land wanneer ik in de concertzaal om me heen kijk; niet alleen het interieur, ook het publiek ziet er armetierig uit. [...] Ik word omringd door vroeg grijze mannen in afgedragen kostuums en kromgebogen dames in verdofte fluwelen jurken, en ik durf te wedden dat ze tijdens de 1 meiviering van 1986 of 1987 dezelfde kleren droegen. (Brokken 2010: 89)

In Litouwen rijdt hij in "een gammele bus" en een taxibusje met een "kaalgeschoren twintiger in leren jack." Over het Russische Kaliningrad schrijft hij: "in weinig steden brandde de lamp van de verlichting helderder, in weinig steden doofde ze abrupter." Er worden ten slotte ook enkele positieve kenmerken

\footnotetext{
${ }^{8}$ Lovende recensies stonden o.a. in de Volkskrant, Literair Nederland, De Standaard en Knack.
} 
vermeld, zoals absurditeit ("Ze zijn in deze streken erg goed in absurde humor") en emotionaliteit ("Als ze in het Noordoosten van Europa eenmaal gaan praten, weten ze van geen ophouden"). Kaliningrad is zelfs een toekomstgerichte en ambitieuze stad: "Er hing iets verwachtingsvols in de lucht. Ik had de indruk dat de stad wachtte. Ongeduldig wachtte op een nieuwe bestemming, een nieuwe toekomst en een nieuwe naam" (Brokken 2010: 125, 197, 216, 243-244).

\section{Conclusie}

Literaire non-fictie, die in de Nederlandstalige literatuur een steeds sterkere positie heeft, bevat stereotypen over Midden- en Oost-Europa die wijzen op een eurooriëntalistisch en balkanistisch discours waarin het IJzeren Gordijn niet verdwenen is. Onderontwikkeling, absolute macht, genotzucht, mysterie en duisternis zijn de belangrijkste toegekende eigenschappen aan de MOE-landen. Terwijl Geert Mak een genuanceerd beeld tracht te geven van de $20^{\text {ste }}$-eeuwse Europese geschiedenis, bevestigt hij in zijn persoonlijke indrukken van de contemporaine aard van de bezochte landen bepaalde stereotypen. In de reisverhalen van Jelle Brandt Corstius is het beeld van onderontwikkeling en genotzucht te vinden. Van de in dit onderzoek aan bod gekomen auteurs brengen Jan Brokken en de huidige Moskoucorrespondent Olaf Koens het minst stereotypische beeld van Rusland en landen die tot de voormalige Sovjet-Unie behoren. Het boek van Joop Verstraten laat de meest negatieve beeldvorming zien en vertoont een duidelijk euro-oriëntalistisch en balkanistisch discours. In de onderzochte literatuur is het imagologische centrum-periferiemodel ten slotte aanwezig, maar niet in overheersende mate. Algemeen beschouwd staat Midden- en Oost-Europa in de periferie van de WestEuropese landen, maar is er ook een tegenstelling binnen de regio zelf. Zo worden de Baltische staten dichtbij het centrum en de landen in Zuidoost-Europa en in de Kaukaus in de periferie geplaatst.

\section{Literatuur}

Baldwin, Elaine (e.a.). 2000. Introducing Cultural Studies. Athens: University of Georgia Press.

Brandt Corstius, Jelle. 2008. Rusland voor gevorderden. Berichten van een overlever.

Amsterdam: Prometheus. 2009. Kleine landjes. Berichten uit de Kaukasus. Amsterdam: Prometheus.

Broer, Thijs. 28 Feb. 2004. "Geert Mak, de bindende buitenstaander." Vrij Nederland. 6 Nov. 2012 <http:/ / www.vn.nl/ Artikel-Literatuur/Geert-Mak-de-bindendebuitenstaander.htm>. 
Brokken, Jan. 2010. Baltische zielen. Amsterdam: Atlas.

Ceelen, Han, en Jeroen van Bergeijk. 2007. Meer dan de feiten. Gesprekken met auteurs van literaire non-fictie. Amsterdam: Atlas.

Chew III, William L. 2006. "What's in a National Stereotype? An Introduction to Imagology at the Threshold of the 21st Century," Language and Intercultural Communication 6 (3): 179-187.

Fortuin, Arjen. 2008. “Goed geschreven non-fictie," De Revisor (2-3): 59-64.

Koens, Olaf. 2012. Koorddansen in de Kaukasus. Reis door Ruslands onbeheersbare achtertuin. Amsterdam: Nieuw Amsterdam.

Leerssen, Joep, en Manfred Beller, eds. 2007. Imagology. The Cultural Construction and Literary Representation of National Characters. A Critical Survey. Amsterdam: Rodopi.

Lievers, Menno. 2008. “Literaire non-fictie: een probleem," De Revisor (2-3): 99-104.

Mak, Geert. 2004. In Europa. Reizen door de twintigste eeuw. Amsterdam: Atlas.

Mourits, Bertram. 2008. "Waar gebeurd is wel degelijk een excuus. De grenzen van literaire non-fictie," De Revisor (2-3): 7-17.

2012. "Journalistiek in chique verpakking: Over Nederlandse literaire non-fictie," Werkwinkel 7 (1): 11-31.

Nederlands Letterenfonds. 2013. Jaarverslag 2013. Amsterdam: Letterenfonds.

Schauvliege, Joke. 2014. Bekendmaking VL-NL-Kandidatuur Frankfurter Buchmesse 2016. 20 Apr. 2014 <http://www.jokeschauvliege.be/content/bekendmaking-vl-nlkandidatuur-frankfurter-buchmesse-2016>.

Todorova, Maria. 1997. Imagining the Balkans. Oxford: Oxford University Press.

Valken, Maarten. 16 Oct. 2012. "De vertaling van Nederlandstalige non-fictie in Frankrijk: een momentopname." Nederlands Letterenfonds. 31 Dec. 2013 <http:// www.letterenfonds.nl/nl/essay/28/de-vertaling-van-nederlandstalige-literaire-nonfictie-in-frankr>.

Verstraten, Joop. 2008. Verhalen van de jongste tijd. Reizen langs de rafelranden van het Sovjetblok. Utrecht: IJzer. 